


\title{
Sin og sig med flertalsantecedent fra runesten til LANCHART
}

\author{
Af Katrine Rosendal Ehlers
}

In modern Danish, the reflexive pronouns sin and sig differ in terms of their ability to corefer with a plural antecedent. The reflexive possessive $\sin$ typically only allows singular antecedents and the reflexive pronoun sig allows both singular and plural antecedents. Instead of $\sin$, speakers use the non-reflexive deres to corefer with a plural antecedent. This difference between sin and sig is fairly new. Up until the beginning of the twentieth century, many speakers used not only sin but also sig primarily with singular antecedents and the non-reflexive counterparts deres and dem with plural antecedents. This usage pattern goes back to before the thirteenth century.

In this paper I investigate the development in the use of sin and sig with plural antecedents. In the earliest runic sources of Danish from before $1000 \mathrm{AD}$, both sin and sig are used with plural antecedents. In the Middle Danish provincial laws from the thirteenth century, sin and sig are both restricted to occurring mainly with singular antecedents. This usage, reflexive pronouns/possessives with singular antecedents and non-reflexive pronouns/possessives with plural antecedents, is found in the spoken language at least until the twentieth century. However, I show with data from the spoken corpus LANCHART that the use of dem with plural antecedents has almost disappeared in modern Danish.

\section{Indledning}

\subsection{Det moderne refleksivsystem: to sig, ét sig selv}

Moderne dansk bruger refleksive pronominer til at udtrykke den situation hvor to elementer inden for den samme sætning refererer til én og samme ting. Det illustrerer jeg i (1) hvor subjektet Carsten og det refleksive sig selv begge henviser til samme person. Carsten er antecedent for refleksivpronominet sig selv og de to elementer korefererer. Den intenderede koreference markeres her ved hjælp af indekser og fed skrift.
(1)
a.
$\operatorname{Carsten}_{1}$ fotograferer sig selv .

1 En stor tak til Sten Vikner, Henrik Jørgensen, Ken Ramshøj Christensen og Simon Skovgaard Boeck, de studerende i KA-valgfaget Syntactic Variation and Change, tilhørerne ved vores foredrag til MUDS i 2016 og Grammatiknetværksmødet i 2016 og 2019 samt den anonyme bedømmer. 
Denne artikel beskæftiger sig primært med de refleksive pronominer sig, sig selv og det refleksive possessivpronomen sin. Det moderne danske refleksivsystem er blandt andet belyst i Vikner 1985, Hvilshøj 2000, Brandt 2001, Juel Jensen 2009, Jensen 2010, Ehlers \& Vikner 2017, Vikner \& Ehlers 2017 og Sørensen, Ehlers \& Vikner 2020. Jeg henviser den interesserede læser til disse artikler for en mere udførlig gennemgang af refleksivsystemet i dansk.

Foranlediget af den anonyme bedømmer, finder jeg det alligevel værd at skitsere det refleksivsystem som jeg anvender som teoretisk baggrund og som er undersøgt empirisk i Ehlers \& Vikner 2017, Vikner \& Ehlers 2017 og Sørensen et al. 2020. Her skelnes mellem to forskellige sig, nemlig sig som argument og sig som ikke-argument. Dertil kommer fuldrefleksivet sig selv som altid er et argument. De tre former, ét sig selv og de to former for sig, er illustreret ved eksemplerne i (2)-(4). En * indikerer at sætningen er ugrammatisk (med den intenderede koreference).
a.
Carsten $_{1}$ skammer
$\operatorname{sig}_{1}$.
b. *
Carsten $_{1}$ skammer $^{2}$
c. $*$
Carsten $_{1}$ skammer
$\operatorname{sig} \operatorname{selv}_{1}$.
Anders.

(3)
a. *
Carsten $_{1}$ fotograferer
$\operatorname{sig}_{1}$.
b. $\quad$ Carsten fotograferer $^{2}$
$\operatorname{sig} \operatorname{selv}_{1}$.
c.
Carsten $_{1}$ fotograferer
Anders.

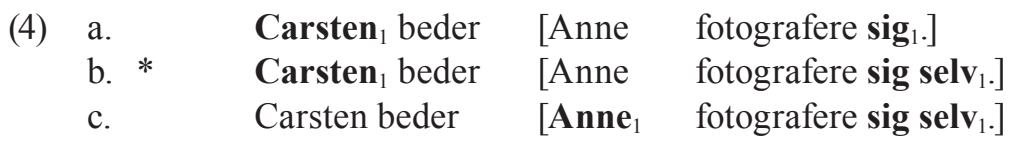

Én gruppe verber, herunder skamme, kan kun have sig som komplement. Denne gruppe bliver også omtalt som de ægte refleksive verber, da de netop kun tager refleksivkomplementer og ikke andet. Man kan skamme sig, (2a), men hverken skamme sig selv, (2b), eller skamme Anders, (2c). Det sig som optræder som komplement til skamme i (2) er et ikke-argument sig, der ikke kan udskiftes med et komplement med argumentstatus (som sig selv eller Anders).

I modsætning til de ægte refleksive verber står en stor gruppe verber, som fotografere i (3), der både tillader et refleksiv og et komplement med argumentstatus, men ikke sig uden argumentstatus. Man 
kan ikke fotografere sig, (3a), men man kan fotografere sig selv, (3b), eller fotografere Anders, (3c). Det er derfor oplagt at spørge hvordan det kan være at sig alligevel kan optræde som komplement til fotografere i (4).

Det sig der optræder i (4), er sig med argumentstatus. Det svarer til argumentet sig selv i (3) og ikke ikke-argumentet sig i (2). Argument sig optræder i komplementær distribution med fuldrefleksivet, betinget af lokalitet. Når koreferencen er ikke-lokal, dvs. når refleksivet står i en indlejret ikke-finit sætning og antecedenten står i matrixsætningen som i (4a-b), er sig den eneste mulige refleksivform, også for verber som kræver sig selv når koreferencen er lokal, (4c). Dette ikke-lokale sig svarer altså til det lokale sig selv og er selv et argument, der kan udskiftes med andre argumenter.

En mindre gruppe verber (herunder vaske, barbere, frisere m.fl.) kan have både ikke-argument sig og argument sig selv som komplement uden at sætningens betydning ændrer sig. Han barberede sig og Han barberede sig selv betyder grundlæggende det samme, og dermed er det svært at opretholde et stærkt argument for at skulle skelne mellem ikke-argument sig og argument sig selv. Denne gruppe diskuteres yderligere i Ehlers \& Vikner (2017) og den primære pointe er at disse verber udgør et mindretal som ikke kan opfattes som det kanoniske refleksiveksempel.

Når jeg i denne artikel undersøger brugen af sig i forhold til brugen af dem, undersøger jeg også sig selv og dem selv. Jeg inkluderer både argument og ikke-argument sig, såvel som sig selv. Hos de skribenter som bruger dem som alternativ til sig, optræder dem både som ikke-argument og som ikke-lokalt argument, helt på linje med hvordan sig kan bruges. Tilsvarende ses dem selv brugt på samme måde som sig selv som det lokale refleksivargument.

Størstedelen af de eksempler, som jeg bruger til at illustrere udviklingen, indeholder sig eller dem og ikke sig selv eller dem selv. Den anonyme bedømmer foreslår at forskellen på sig og sig selv som i Han barberede sig og Han barberede sig selv er af relativt ny dato og det er uden tvivl et spørgsmål, der er værd at undersøge nærmere. I mit datamateriale finder jeg ikke evidens for at denne forskel er meget ny: I samtlige eksempler fra 1500 og frem optræder sig og sig selv (og tilsvarende dem og dem selv for de skribenter, der bruger dem som alternativ til sig) i de samme kontek- 
ster, som man ville forvente at se dem i dag, jf. eksemplerne fra Chr. III's Bibel i (5a-d). ${ }^{2}$

(5) a. Oc fulene formere $_{1} \mathbf{s i g}_{1}$ paa iorden. (1. Mos., 1.22)

b. Da tenckte de $\mathbf{d e}_{1}$ ved sig selff / $_{1}$ oc sagde (Matt., 21.25)

c. Oc see / nogle blant de Scrifftklaage sagde ved dem selffue $_{1}$ / (Matt., 9.3)

d. Oc der ere nogle Gillinge / som haffue gillet dem selff I $_{1}$ for Himmerigis rige skyld. (Matt., 19.12)

At sig alligevel er den hyppigste form i eksemplerne i artiklen, er en konsekvens af relativ hyppighed. Formen sig er langt mere hyppigt brugt end sig selv, både i mit ældre datamateriale og i det moderne sprog. I KorpusDK optræder pronominet sig omtrent 270.000 gange og sig selv cirka 20.000 gange. Sig er altså mere end ti gange så hyppig som sig selv i det moderne sprog og noget lignende lader til at være gældende for det ældre sprog.

\subsection{Entals- og flertalsantecedent}

(6) og (7) illustrerer den forskel mellem sig og sin som er omdrejningspunktet for artiklen her. For sig og sig selv gælder at antecedenten enten kan være ental som i (6a-b) eller flertal som i (6c-d).
a. Anne
fotograferer
sig selv
b. Anne glæder $\operatorname{sig}_{1}$.
c. Vennerne fotograferer $\operatorname{sig} \mathbf{s e l v}_{1}$.
d. Vennerne $_{1}$ glæder $\operatorname{sig}_{1}$.

For $\sin$ gælder at antecedenten kun meget sjældent er flertal; her bruges normalt den ikke-refleksive form deres i stedet med refleksiv betydning, (7b-c). Dette er i modsætning til norsk og svensk, hvor både sin og sig bruges med flertals- og entalsantecedenter: (7d-e) fra Hinchliffe \& Holmes (2018: 54), (7f-g) fra Holmes \& Enger (2018: 163).

2 Det skal bemærkes at fokus for min dataindsamling ikke har været at belyse dette spørgsmål, og at det relevante datagrundlag for ældre og yngre nydansk derfor er meget småt. Det er derfor stadig et åbent spørgsmål, hvornår sig og sig selv blev de to forskellige refleksivformer, som jeg mener, at de er i dag, men datamaterialet peger altså på, at denne forskel formentlig blev etableret før 1500. 


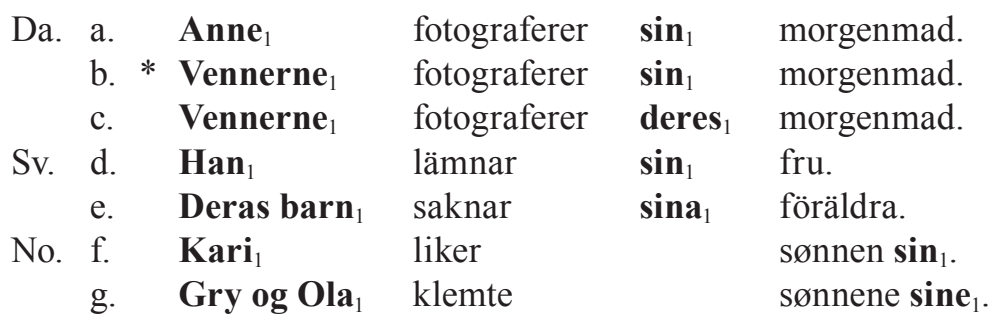

For hverken sig eller sig selv er det muligt at anvende den ikke-refleksive form, dem: både (8a) og (8b) er ugrammatiske med den tiltænkte koreference. Det er naturligvis muligt at sige vennerne fotograferer dem selv eller vennerne glceder dem, men så kan dem kun være en tredjepart, der bliver fotograferet eller glædet, og ikke vennerne selv.
a. * Vennerne fotograferer $_{1}$
b. * Vennerne ${ }_{1}$ glæder
dem selv $v_{1}$.
$\operatorname{dem}_{1}$.

Denne forskel på mulige antecedenter for sig og sin er en meget moderne forskel, da man i det ældre danske sprog netop brugte både dem og deres refleksivt med henvisning til flertalsantecedenter. I Chr. III's Bibel fra 1550 kan man finde mange eksempler på refleksivt dem, fx i (9) fra 1. Mosebog, 3.8. I den autoriserede oversættelse fra 1992 skal Adam og hans hustru gemme sig, ikke gemme dem (verbet er ændret i den moderne oversættelse).

(9) $1550 \mathrm{a}$.

Da skiulte Adam oc hans hustru dem $_{1}$ for Guds HERRENS ansict / blant træerne i haffuen.

I moderne dansk sker det omvendt ganske ofte at man hører eller læser sin med flertalsantecedent, som eksempelvis (10).

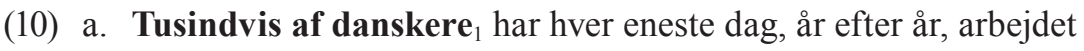
for at forsørge sig selv og $\sin _{1}$ familie...

(Mette Frederiksen, nytårstale, 1/1 2020, 11:08 i video på dr.dk)

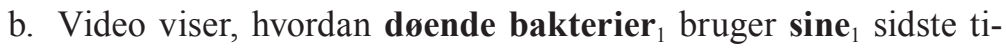
mer på at sikre andre bakteriers overlevelse.

(DR.dk, 22/11 2019)

Ét spørgsmål er om denne brug kan siges at være en stabil variant eller et tegn på en mulig sprogforandring i tråd med den udvikling, som sig 
har været igennem. Den moderne brug af $\sin$ med flertalsantecedent omtales kort i både Juel Jensen (2009) og i Vikner og Ehlers (2017) og i mit igangværende ph.d.-projekt (Ehlers under forberedelse) undersøger jeg selv denne mulige udvikling i brugen af sin med flertalsantecedent nærmere. Den moderne variation behandles ikke yderligere i nærværende artikel af pladshensyn, men i afsnit 3.2 undersøger jeg forekomsten i et udvalg af tekster fra ældre og yngre nydansk op til 1900-tallet.

I denne artikel giver jeg et historisk rids af hvordan sig og $\sin$ (og dermed dem og deres) har været brugt i dansk de seneste tusind år. Afsnit 2 behandler refleksiverne som de blev brugt på runesten og i de tidlige danske landskabslove. Her konkluderer jeg, at dem og deres har været brugt som refleksiver med flertalsantecedent helt tilbage til 1200-tallet (og måske tidligere endnu). I afsnit 3 inddrager jeg tekstmateriale fra 1500-1900 og belyser bl.a. variationen i refleksivbrugen i Chr. III's Bibel fra 1550, hvor andelen af refleksivt sig er noget højere end forventet. I afsnit 4 undersøger jeg moderne talesprogsdata fra LANCHART for at afdække $\mathrm{i}$ hvor høj grad det refleksive $d e m$ stadig er i brug i dag.

\section{Refleksiverne i runedansk og middeldansk}

Sig og sin fungerede som refleksive pronominer i både fællesgermansk og urnordisk og tillod både entals- og flertalsantecedenter (se fx Mikkelsen 1911: 266). I Grammatik over det danske sprog, GDS (Hansen og Heltoft 2012: 590) fremgår det, at sin har været brugt med flertalsantecedenter i ældre dansk både på runesten fra 800-tallet, (11a), i den ældste bibeloversættelse fra slutningen af 1400-tallet, (11b), og i Mallings Store og gode Handlinger af Danske, Norske og Holstenere fra 1777, (11c). Forfatterne bemærker dog også at deres også har været brugt refleksivt helt tilbage til 1200-tallets skånske lovtekster.

(11) c800 a. Alla syniR 1 gærpu kumbl pøsi æft fapur $\sin _{1}$ Alles [mandsnavn] sønner gjorde disse kumler efter fader sin

c1500 b. the $\mathbf{s}_{1}$ skulle plawes for $\mathbf{s y n}_{1}$ fathers, og synæ $\mathbf{x}_{1}$ syndhe de skal pines for sin faders (el. forfoedres) og sine egne synder

1777 c. [han] klappede paa Kaarden: og spurgde: om Officererne havde baaret $\sin _{1}$ Værge saa kiekt i Fyen, som han og hans Borgere i Kiøbenhavns Beleiring. 
Det er formentlig ikke tilfældet, at sin og deres (og sig og dem, som dog ikke nævnes i GDS i denne forbindelse) bare har været mere eller mindre valgfrie varianter af hinanden op gennem (sprog)historien. Allerede i de tidligste danske tekster efter runedansk-perioden ser vi en indskrænkning for både sig og sin, således at sig og sin i en lang periode i skriftsproget primært anvendes med entalsantecedenter, mens dem og deres anvendes refleksivt med flertalsantecedenter. I (12) gengiver jeg eksempler fra Skånske Lov på henholdsvis sin og sig brugt med reference til entalsantecedent. I (12a) henviser sin til bonden og i (12b) henviser sig til han. Bemærk at sce i (12b) afspejler dativformen, som kun er belagt med sikkerhed i gammeldansk i de skånske lovtekster (Frederiksen 2019: 65) og altså i de andre gammeldanske kilder og i senere sprogformer er erstattet af akkusativformen sig.

(12) c1200 a. gifær bondæ sinum $_{1}$ barnebørnum iorp giver bonden sine børnebørn jord (Skånske Lov, kapitel 37, tekstnet.dk)

b. uarpær man usæl ok fatøkær sua at han ma bliver mand ussel og fattig så at han må

æi sialfær hialpæ $\mathbf{s æ}_{1}$ ikke selv hjælpe sig

Bliver en person så hjcelpeløs og fattig, at han ikke selv kan klare sig...

(Skånske Lov, kapitel 41, tekstnet.dk, oversættelse cf. Kroman 1945, forfatterens glossering)

I (13) er ligeledes et uddrag fra Skånske Lov (Codex Runicus-håndskriftet), men her er der tale om flertalsantecedenten de. De refleksive pronominer er her ikke sin og sig som for entalsantecedenterne i (12), men dem (at de kan ikke brødføde dem) og deres (de salger deres jord). I oversættelsen bruges sig og deres i overensstemmelse med moderne sprogbrug. Det skal bemærkes at brugen af dem i (13) er usædvanlig, da håndskrifterne af Skånske Lov overvejende har sig henvisende til flertalsantecedenter, og at flere andre håndskrifter samme sted har sig i stedet for dem (Brøndum-Nielsen 1965: 32). 
(13) c1200 a.

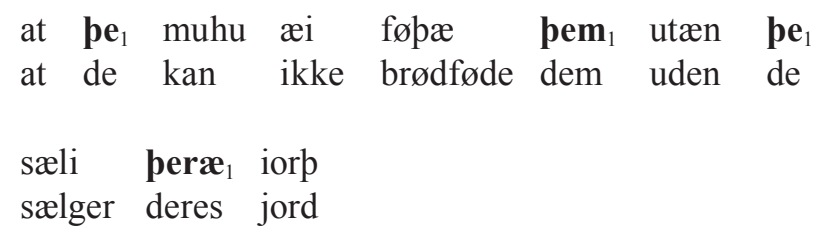

... at de ikke kan ernoere sig uden at scelge deres jord... (Skånske Lov, kapitel 48, tekstnet.dk, oversættelse cf. Kroman 1945, forfatterens glossering)

Den forskel på sin og deres som fremgår af (12a) og (13), holder stadig ved: I moderne dansk bruges sin næsten udelukkende med reference til entalsantecedenter og deres til flertalsantecedenter. Sig, derimod, har genvundet muligheden for at henvise til både entals- og flertalsantecedenter. I de følgende afsnit følger jeg i nærmere detaljer udviklingen af brugen af sig og dem samt sin og deres fra runesten til slutningen af den middeldanske periode.

Jeg følger den hovedinddeling af sproghistoriske perioder, som fremgår af den nye store danske sproghistorie (Jørgensen 2016: 80). Perioden 800-1100 kaldes olddansk eller runedansk efter periodens skriftsprog. Omkring 1100 begynder man at skrive dansk med latinske bogstaver frem for runer, og man har derfor valgt at lægge et skel her. Perioden 1100-1500 kaldes middeldansk eller gammeldansk, og inddeles i en ældre middeldansk periode (1100-1350) og en yngre middeldansk periode (1350-1500). Efter 1500 bliver middelalderens håndskrevne dansk efterhånden suppleret med trykt materiale og denne overgang markerer endnu et sproghistorisk skel ind i ældre (1500-1700) henholdsvis yngre nydansk (1700-nu).

\subsection{Runedansk (800-1100)}

På http://runer.ku.dk/Search.aspx har Københavns Universitet og Nationalmuseet en søgbar database med indskrifterne fra samtlige danske genstande med runer (eller mere specifikt, samtlige genstande fra det område, som udgjorde Danmark i middelalderen, herunder også Skåne og Slesvig). Databasen rummer omkring 900 runeindskrifter. Databasen indeholder materiale både fra jernalder og middelalder og de yngste genstande er dermed jævnaldrende med de ældste håndskrifter. Ingen af genstandene med sin med flertalsantecedent er dog senere end 1125 og samtlige eksempler dateret mellem 1025 og 1125 stammer fra Bornholm. 
De resterende genstande er dateret til mellem år 900 og 1020 og er fordelt ud over hele Danmark, herunder Skåne.

Jeg har søgt på deres, sin, dem og sig i fritekstsøgningen og gennemgået resultaterne manuelt. En mulig faldgrube ved denne søgestrategi er, at der kan være gået materiale tabt fra original inskription til den danske oversættelse, måske som konsekvens af fejlagtig eller mangelfuld oversættelse. Det kan fx ses i oversættelsen af teksten på Kuregård-stenen i (14), hvor sin i translitterationen bliver til sinn i transskriptionen og igen sin i den danske oversættelse. I oversættelsen skulle sin have været oversat til deres i overensstemmelse med den moderne norm. Ved at medtage både sin, deres, sig og dem i søgningen, burde lignende oversættelsesfejl dog ikke udgøre et problem. Jeg har desuden foretaget søgninger på sin i den translittererede tekst og sinn i transskriptionen og har kun fundet den ene omtalte oversættelsesfejl.

(14) suin : auk : ketil $_{1}$ : reistu : sten : eftiR : (i) $\mathrm{u}(1) \mathrm{k} \mid \mathrm{iR}$ : fapur : $\sin _{1}$ Svénn ok Kcetill réstu stén aftiR Ílg]ulgéR, fapur sinn.

Sven og Ketil rejste stenen efter Igulger, sin fader.

(Translitteration, transskription og oversættelse fra runesten fundet på Bornholm, c.1025-1075)

Der er 30 genstande i databasen, der indeholder ordet deres i den moderne danske oversættelse af teksten. Flere af genstandene indeholder mere end ét deres, så der er i alt 32 deres i databasen. Af disse 32 er der 27, hvor deres er refleksiv, og fem hvor deres ikke er refleksiv. Af de fem er der én, hvor man i den moderne oversættelse har indsat et pronomen, der ikke er i den originale indskrift. I alt finder jeg 28 eksempler på possessive refleksiver med flertalsantecedent: de 27 fra søgningen på deres og det ene eksempel i (14). Jeg giver eksempler på refleksivt anvendt deres i (15) og ikke-refleksivt anvendt deres i (16). Begge indskrifter samt oversættelsen til moderne dansk er taget direkte fra runedatabasen og er repræsentative for resten af deres-indskrifterne.

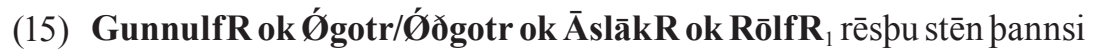
æftiR Fūl, fēlaga $\operatorname{sinn}_{1}$, eR varð ... dǿðr, pā kunungaR barðusk. Gunulv og Øgot og Aslak og Rolf rejste denne sten efter deres falle Ful. Han fandt døden ... da konger kcempede.

(Transskription fra en runesten fundet ved Hasle, Aarhus V, dateret c.970-1020) 
(16) Krist hælgi hialpi siolu peRa brøpra bæggia.

Den hellige Krist hjcelpe deres, begge brødres, sjcele. ${ }^{3}$

(Transskription fra en runesten fundet ved Nyker, Bornholm, dateret c.1075-1125)

I eksempel (15) henviser deres til sætningens subjekt Gunulv og Øgot og Aslak og Rolf og er altså refleksivt anvendt. Her er det moderne deres en oversættelse fra sinn, det refleksive possessivpronomen. I eksempel (16) henviser deres ikke til et subjekt inden for sætningen og er altså ikke refleksivt anvendt. Her er det moderne deres en oversættelse fra $p e R a$, en possessivt anvendt genitiv pluralis. Dette er det gældende system for samtlige 32 relevante deres: når deres $\mathrm{i}$ den moderne oversættelse er refleksivt anvendt, er deres en oversættelse af det refleksive possessivpronomen sin (i forskellige bøjningsvarianter); når deres i den moderne oversættelse ikke er refleksivt anvendt, er deres en oversættelse af det ikke-refleksive, possessivt anvendte demonstrative pronomen. Runeindskrifterne repræsenterer altså konsistent en grammatik, hvor $\sin$ anvendes som refleksivpronomen med entals- og flertalsantecedenter og deres kun anvendes i de ikke-refleksive tilfælde.

Det er ikke muligt at lave samme observation i forhold til anvendelsen af sig og dem, men det er formentlig udelukkende et spørgsmål om mangel på materiale. Sig optræder på 34 genstande, hvoraf 30 af forskellige årsager ikke kan bruges til indeværende undersøgelse. På de fire genstande der kan bruges, henviser sig udelukkende til entalsantecedenter. Dem optræder på tre genstande i databasen. Heraf kan de to ikke bruges da originalteksten er latin. På den tredje genstand er dem anvendt ikke-refleksivt. Det er altså ikke muligt, ud fra runeindskrifterne alene, at sige noget om hvorvidt dem kunne anvendes refleksivt eller om hvorvidt sig kunne anvendes med flertalsantecedenter. Det virker dog ikke urimeligt at antage, at sig og dem ville have fulgt det samme system som sin og deres, med sig som den refleksive form som kunne bruges med både entals- og flertalsantecedenter og dem som det ikke-refleksive modstykke til sig.

3 Den anonyme bedømmer vurderer at runedatabasens oversættelse her formentlig ikke er dækkende. Bedømmeren foreslår Den hellige Krist hjcelpe de to brødres sjcele eller ... hjoelpe deres sjcele, de to brødres som alternativer. 


\subsection{Middeldansk (1100-1500)}

De følgende afsnit bygger primært på materiale fra Diderichsen (1939). Det er en indholdsrig artikel om brugen af refleksiver i dansk, men den er ikke altid udpræget tilgængelig at læse. Af samme årsag gør jeg her et forsøg på at gøre nogle af Diderichsens data mere tilgængelige.

Diderichsen (1939) indeholder, blandt meget andet, en undersøgelse af anvendelsen af pronominer med flertalsantecedenter i nogle af de gamle landskabslove: Skånske Lov, Valdemars Sjcellandske Lov, Eriks Sjcellandske Lov og Jyske Lov. Undersøgelsen er en reaktion på de nedenfor citerede påstande fra Falk og Torp.

I slutningen af 15. aarh. blev »dem« det fremherskende, maaske tildels under indflydelse af det adjektiviske refleksiv [sin], som efter mønster af det tyske »ihr« lød »deres« $[\ldots]$

Navnlig blev fra reformationstiden af ved indflydelse af tysk (»ihr«) pronomenet »deres « almindeligt, hvor der henvises til et flertalsord; saaledes stadig hos Chr. Pedersen. Denne brug er trængt helt igjennem i dansk (Falk og Torp 1900: 131-4)

Den brug af dem og deres som Falk og Torp siger bliver den fremherskende i slutningen af 1400-tallet og frem, er brugen af dem og deres (frem for sig og $\sin$ ) som refleksiv med flertalsantecedent. Jeg illustrerer denne angiveligt nye brug i eksemplerne i (17) fra Chr. III's Bibel fra 1550 (1. Mosebog, 6.3 og 8.5).

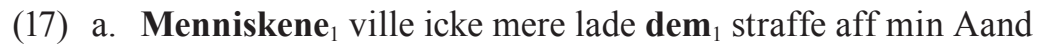

b. Paa den første dag i den tiende Maaned lode toppene aff Biergene $_{1}$ dem $_{1}$ til siune.

... første dag i den tiende måned kom bjergtoppene til syne. (aut. oversættelse, 1992)

I det tidligere sprog, som beskrevet i afsnittet om runedansk, blev sin og sig brugt både med entals- og flertalsantecedenter, mens dem og deres blev brugt ikke-refleksivt. Ifølge Falk og Torp skete der altså et skifte i brugen omkring år 1500, således at sin og sig blev brugt som refleksiver ved henvisning til entalsantecedenter og deres og dem blev brugt som refleksiver ved henvisning til flertalsantecedenter. 
Som Diderichsen (1939: 71) påpeger, er det dog værd at forholde sig lidt kritisk til Falk og Torps beskrivelser med hensyn til datering og med hensyn til årsagen til denne sprogforandring. Jeg begynder her med en diskussion af årsagssammenhængen og fortsætter med en diskussion af dateringen i næste afsnit.

\subsubsection{Tysk indflydelse?}

Falk og Torp foreslår altså at dem blev anvendt refleksivt, fordi talere generaliserede fra den refleksive anvendelse af deres. På grund af tysk indflydelse begyndte talere at bruge deres (frem for sin) med reference til flertalsantecedenter. Denne brug skulle så have skubbet dem i samme retning sådan at sig efterfølgende kun kunne bruges med entalsantecedenter, og dem efterfølgende kun kunne bruges refleksivt med reference til flertalsantecedenter. Logikken bag påstanden om den tyske indflydelse må være at det tyske sein, svarende til det danske $\sin$, er et singularispronomen. På tysk kan sein ikke bruges med reference til flertalsantecedenter eller entalsantecedenter i hunkøn, og ihr bruges i stedet (svarende til deres henholdsvis hendes). Sein er ikke et refleksivpronomen, men et possessivpronomen i han- og intetkøn, der kan bruges både refleksivt som i (18) og ikke-refleksivt som i (19).

(18) Ty. $\quad \mathbf{E r}_{1}$ liebt seine $_{1}$ Mutter. han elsker sin mor

(19) Ty. Seine Mutter ist sehr nett. hans/dens mor er meget rar

Hvis deres kunne anvendes refleksivt på grund af tysk indflydelse, kunne vi måske forvente at se et system ikke bare med numerus-forskelle, men også med forskelle i genus. Det ville altså sige et system, hvor sin er begrænset til han- og intetkøn, og hvor talere bruger deres med flertalsantecedenter og hendes med hunkønsantecedenter. Det er faktisk, hvad vi ser i de jyske dialekter med kraftig påvirkning fra tysk, som de taltes i 18-1900-tallet i nogle dele af Slesvig (Jul Nielsen 1986: 51, 75-79), inklusive i Fjolde (Bjerrum og Bjerrum 1974: 23-24). Herfra beskriver Noesgaard (1951: 74, citeret i Jul Nielsen 1986: 51) at »Nogle elever, især med tysk skolegang, anvender $\sin$ hvor tyskerne bruger sein [...]s Den tyske sætning: 'Er nahm seinen Hut' bliver altså til den danske: 'Han tog sin hat', medens det tyske: 'Sie nahm ihren Hut', bliver til: 'Hun tog hendes 
hat'«. Det kunne være interessant at undersøge hvorvidt denne mulige tyske indflydelse faktisk kan påvises (eller afvises) i de ældre tekster, men det ligger uden for rammen af denne artikel.

Hvad der end er tilfældet med sin og deres og eventuel indflydelse fra tysk, vil de tyske forhold formentlig trække i en anden retning for sig. Det tyske sich, svarende til dansk sig, kan bruges med reference både til entals- og flertalsantecedenter. Forventningen må derfor være at kraftig tysk indflydelse ville fordre bevarelsen af sig med henvisning til både entals- og flertalsreference. Denne forudsigelse bliver dog ikke umiddelbart understøttet af sproget i de tyskpåvirkede dialekter som jeg omtalte ovenfor: I Fjolde brugtes dem refleksivt med henvisning til flertalsantecedent og sig med henvisning til entalsantecedent (Bjerrum og Bjerrum 1974: 24), og Jul Nielsen bemærker bare at dem som refleksiv er hyppigt brugt $i$ de jyske dialekter. Det er altså et snævert materiale at konkludere noget ud fra, så jeg vil bare konstatere, at der selv i et så tyskpåvirket område som Fjolde ikke ser ud til at være den store indflydelse fra sich på sig.

\subsubsection{Datering: dem/deres var det hyppigst brugte allerede i 1200}

Spørgsmålet er nu også hvorvidt, det kan passe, at udviklingen hen imod en singularis-pluralis-opdeling imellem sig/dem og sin/deres skete så sent som Falk og Torp siger, altså omkring 1500. I (13), gengivet her som (20), er der et eksempel på at dem og deres bliver anvendt refleksivt i Skånske Lov fra omkring 1200.

$$
\begin{aligned}
& \text { c1200 a. at } \text { pe }_{1} \text { muhu æi føpæ } \text { pem }_{1} \text { utæn } \mathbf{p e}_{1} \text { sæli } \\
& \text { at de kan ikke brødføde dem uden de sælger } \\
& \text { beræ } 1 \text { iorb } \\
& \text { deres jord } \\
& \text {... at de ikke kan erncere sig uden at scelge deres jord... }
\end{aligned}
$$

(Skånske Lov, kapitel 48, tekstnet.dk, oversættelse cf. Kroman 1945, forfatterens glossering)

Falk og Torp (1900: 131) bemærker også at både dem og sig blev anvendt ved flertalsantecedenter allerede i de gamle landskabslove, dvs. fra det 12. og 13. århundrede, så de anerkender at dem kunne bruges refleksivt allerede da. Dem blev bare først den hyppigst brugte form omkring år femtenhundrede. Diderichsen (1939: 73-4) efterprøver denne påstand empirisk, og i figuren i (21) reproducerer jeg hans data i mere overskuelig 
form. Data til figuren kommer fra Diderichsens optælling af de former, der er hyppigst i de forskellige håndskrifter, som han har undersøgt. De gange hvor Diderichsen noterer, at et eller flere håndskrifter har en anden form, er disse alternativer ikke repræsenteret i figuren i (21).

FIGUR 1. DATA FRA DiderichSEN (1939: 73-4). BRUGEN AF DEM, SIG, DERES OG SIN MED FLERTALSANTECEDENT I FIRE TIDLIGE LANDSKABSLOVE.

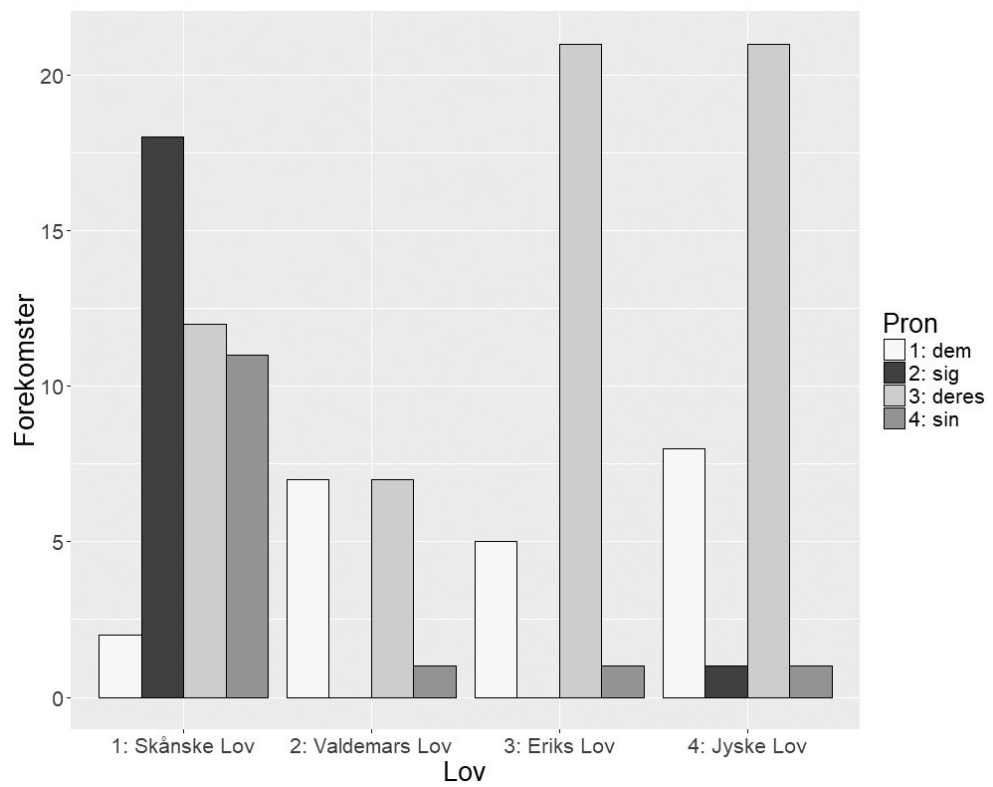

Skånske Lov er ud fra indholdet vurderet til at vere fra begyndelsen af 1200-tallet. Valdemars Sjcellandske Lov er på samme måde vurderet til at veere fra forste halvdel af 1200-tallet. Eriks Sjollandske Lov er vurderet til at voere fra midten af 1200-tallet. Jyske Lov er ifolge lovens fortale fra 1241. De forskellige bevarede håndskrifter er yngre; de celdste er fra omkring 1300 med Holm B 74 (Skånske Lov, ca. 1250) og Holm C 37 (ca. 1280?) som undtagelser.

Figur 1 er opdelt i forhold til de fire undersøgte love, Skånske Lov, Valdemars Lov, Eriks Sjcellandske Lov og Jyske Lov. For hver lov viser søjlerne forekomsten af henholdsvis dem, sig, deres og sin brugt refleksivt med henvisning til en flertalsantecedent.

I Skånske Lov underbygger data Falk og Torps beskrivelse af det daværende sprog med hensyn til dem og sig. Både dem og sig bliver brugt med reference til flertalsantecedent, men sig (18 forekomster) er langt hyp- 
pigere brugt end dem (2 forekomster). Til gengæld er brugen af sin og deres mindre klart opdelt: både $\sin$ og deres bliver brugt med reference til flertalsantecedenter, og forekomsten er nogenlunde ens (11 sin, 12 deres).

I lovene fra Sjælland og Jylland er situationen en anden. Her bruges dem og deres næsten udelukkende frem for sig og sin. I Valdemars Sjællandske Lov er der syv forekomster af både dem og deres, men ingen af sig og kun én af sin. I Eriks Sjællandske Lov er der fem forekomster af dem og 21 forekomster af deres. Der er ingen sig og kun ét sin. I Jyske Lov er der otte dem, 21 deres og én af både sig og sin. Det må altså siges, at det kun er i Skånske Lov, at sproget passer på Falk og Torps beskrivelse, når de siger at både dem og sig blev brugt i lovene. I de tre andre love er brugen af dem og deres frem for sig og sin næsten fuldkommen gennemført. Det ser altså ud til, ud fra Diderichsens data, at dem og deres allerede var de mest hyppige former i det danske sprog fra det 13. århundrede og frem. Det er således ikke tilfældet, som Falk og Torp siger, at der skete et markant skifte hen imod brugen af dem og deres omkring 1500: Det skifte var allerede gennemført meget tidligere, således at det var det fremherskende i skriftsproget allerede fra omkring 1200 .

\subsubsection{Brugen af $\sin$ med entalsantecedent i lovene}

I forlængelse af Diderichsens undersøgelse af brugen af pronominer med flertalsantecedent i lovene, er det værd at inkludere en undersøgelse af brugen af pronominer med entalsantecedent i det samme materiale. Man kunne forestille sig at den udvikling der ses fra runeindskrifterne til håndskrifterne i lovene, dvs. hvor sig og sin stort set ikke bliver brugt med reference til flertalsantecedenter i de vestdanske love, er en generel udvikling for sig og sin, således at også reference til entalsantecedenter varetages af ikke-refleksive pronominer. Dette viser sig dog ikke at være tilfældet: Sin er langt den hyppigst brugte form med reference til entalsantecedenter. Det er altså kun med reference til flertalsantecedenter, at der er sket et skifte i sproget væk fra brugen af $\sin$. Jeg har endnu ikke haft mulighed for at lave en tilsvarende undersøgelse i forhold til brugen af sig, men jeg antager at samme forhold må gøre sig gældende.

I figur 2 i (22) gengiver jeg data fra Wellejus (1972: 130-7). Dennes primære formål er at belyse hvilke sproglige træk der kan bruges til at skelne mellem skånske, sjællandske og jyske tekster. Brugen af possessive pronominer frem for $\sin$ bliver ofte fremhævet som et jysk sprogfænomen (ofte illustreret ved sætningen Han tog hans hat og gik hans vej). Af samme grund inddrager Wellejus brugen af hans, hendes og sin brugt 
refleksivt med reference til entalsantecedenter i de ældre håndskrifter. Det viser sig, måske overraskende, at der både i de jyske og sjællandske håndskrifter optræder refleksiv brug af hans og hendes, men at sin trods alt er langt den hyppigste form.

Svarende til gengivelsen af data fra Diderichsen viser jeg også Wellejus' data som graf. Det giver, må det bemærkes, et nødvendigt fald i detaljerigdom, siden Wellejus' undersøgelse indeholder langt mere information om forekomsten af pronominer i variantapparatet, altså i de andre håndskrifter, der også indeholder versioner af lovene. Jeg har ikke kunnet inkludere informationen fra variantapparatet i den databearbejdning, som jeg har fundet nødvendig for at kunne lave en graf over tallene i undersøgelsen, men henviser den detaljeinteresserede læser til Wellejus (1972). Wellejus undersøger mange flere tekster, end jeg har valgt at gengive her, men for samtlige undersøgte tekster (både ældre og yngre) er tendensen den samme: sin er langt den hyppigst brugte form og hans/hendes optræder af og til refleksivt i både jyske og sjællandske tekster. Eriks Sjællandske Lov, som jeg har valgt at gengive i figur 2, er den af Wellejus' undersøgte sjællandske love med den højeste forekomst af hans/hendes i forhold til sin.

(22) FIGUR 2. REFLEKSIVT ANVENDTE POSSESSIVE PRONOMINER MED REFERENCE TIL ENTALSANTECEDENT I TRE LANDSKABSLOVE. DATA FRA WELLEJUS (1972: 130-7).

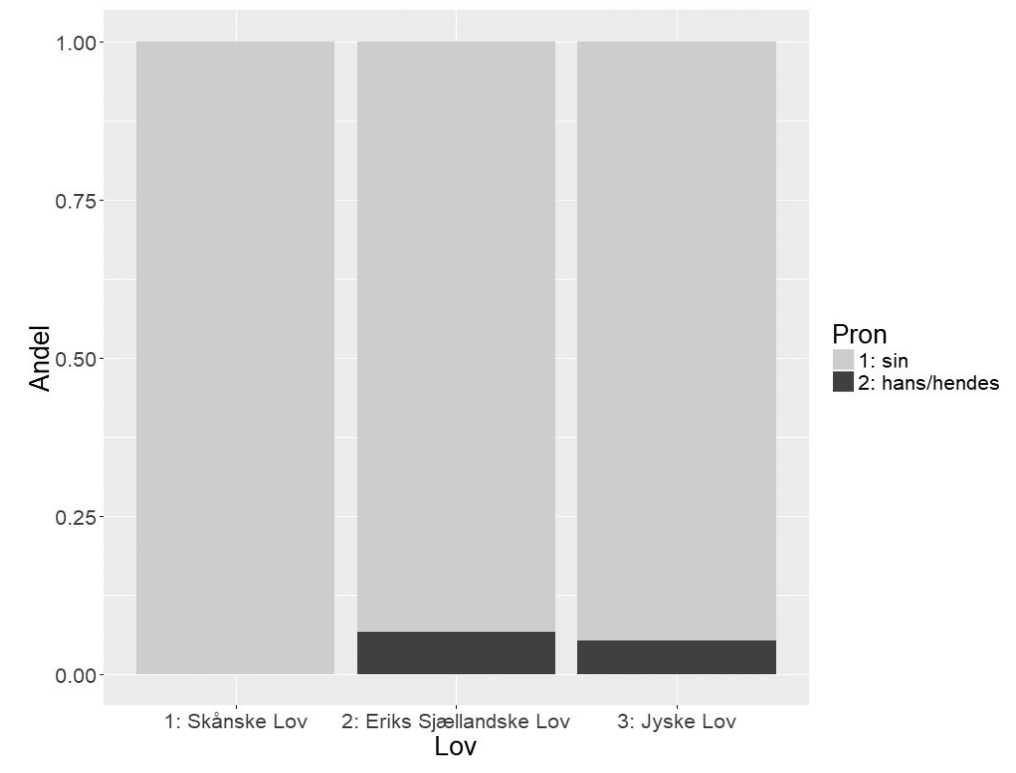


I figur 2 ses forekomsterne af henholdsvis sin og hans/hendes med entalsantecedenter for tre love, Skånske Lov, Eriks Sjællandske Lov og Jyske Lov. Søjlerne viser andelen af henholdsvis sin og hans/hendes i de tre love: når Skånske Lov har en andel på 1,0 af sin, svarer det til at Skånske Lov har 100 \% sin. Skånske Lov adskiller sig klart fra de to andre. Den skånske tekst indeholder ingen eksempler på refleksivt anvendt hans eller hendes, så i samtlige refleksive konstruktioner anvendes der $\sin$. Samtidig viser Wellejus' undersøgelse af variantapparatet, at der kun forekommer ét eksempel på et refleksivt anvendt hans/hendes på tværs af samtlige undersøgte versioner af Skånske Lov. Dette er fint i tråd med Diderichsens data, hvor Skånske Lov også fremstår væsentligt forskellig fra de vestdanske love ved den hyppigere brug af refleksiverne sin og sig frem for dem og deres.

I både Eriks Sjællandske Lov og Jyske Lov er det langt overvejende sin (og ikke hans/hendes), der bliver brugt refleksivt. I Eriks Lov forekommer sin i refleksiv anvendelse 283 gange og hans/hendes i refleksiv anvendelse 20 gange. I Jyske Lov forekommer $\sin 231$ gange og hans/hendes 13 gange. I variantapparatet til begge tekster forekommer hans/hendes af og til refleksivt, hvor det primære håndskrift har sin. Ud fra tallene konkluderer jeg, med Wellejus, at der her ikke er den store forskel på de sjællandske og de jyske håndskrifter med hensyn til brugen af $\sin$ og hans/hendes. Mikkelsen (1911: 266) noterer at muligheden for at anvende hans/hendes refleksivt ganske vist optrådte både i de jyske og sjællandske love, men at det efterfølgende primært var i de jyske dialekter at brugen blev bevaret.

I nærværende artikels sammenhæng kan jeg desuden konkludere, at det primært er med reference til flertalsantecedenter, at refleksivsystemet var blevet ændret i tiden mellem runeindskrifterne og håndskrifterne: Med reference til entalsantecedenter var sin (og antageligt også sig, selvom jeg ikke har data på det) stadig den fremherskende form. Jeg kan endvidere konstatere at variation mellem refleksiv anvendelse af $\sin$ og hans/hendes ikke kan siges at være en nyt dansk sprogtræk, lige som variation mellem sin og deres (og sig og dem) også lader til at have været til stede i sproget allerede for omtrent 800 år siden.

\section{Refleksiverne i ældre nydansk (1500-1700)}

I de foregående afsnit nåede jeg med Diderichsen og Wellejus den konklusion, at dem og deres har været brugt som refleksiver med flertalsantecedenter i hvert fald siden 1200-tallet, mens sin (og formentlig sig) har været 
brugt som refleksiv med entalsantecedenter. I moderne standarddansk kan sin stadig kun bruges med entalsantecedenter og deres bliver brugt refleksivt med reference til flertalsantecedenter. For sig og dem er der dog sket et skifte i standardsproget: her kan sig bruges refleksivt både med entals- og flertalsantecedenter, mens dem ikke kan bruges som refleksiv form, når antecedenten befinder sig i samme sætning som dem. I eksemplerne i (23) ses hvordan sin og deres har en klar arbejdsdeling, hvor sin bruges med reference til ental og deres med reference til flertal. I (24a-b) ses hvordan sig kan bruges både med reference til ental og flertal, og i (24c) ses at sig ikke bare kan, men også skal, bruges med reference til flertal. (24d) er et eksempel på at dem faktisk kan fungere som refleksiv, så længe dem er bundet ikke-lokalt og dermed står tilpas langt væk fra sin antecedent (hvordan man måler at noget er tilpas langt væk præciseres yderligere i Ehlers \& Vikner 2017).

(23) a. Ja, og hun 1 spiser $\sin _{1}$ mad, indskød pigen. (KorpusDK)

b. * Det var, mens de $\mathbf{d e}_{1}$ sad og spiste $\sin _{1}$ mad i middagsstunden...

c. Det var, mens de de $_{1}$ sad og spiste deres ${ }_{1}$ mad i middagsstunden... (KorpusDK)

(24) a. $\quad \mathbf{H a n}_{1}$ glæder sig til familie-forøgelsen, og han skal igen med til fødslen. (KorpusDK)

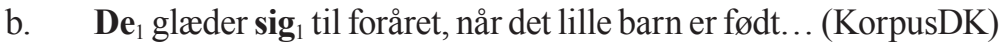

c. * De $_{1}$ glæder $\mathbf{d e m}_{1}$ til foråret, når det lille barn er født... (konstrueret)

d. $\quad$ De $_{1}$ var klædt som forretningsmænd og bad mig køre dem $_{1}$ til South Bronx. (KorpusDK)

Spørgsmålet er nu hvornår sig kom ind i standardsproget igen med reference til flertalsantecedenter (og dem tilsvarende mistede denne mulighed), og hvorvidt der kan ses en tilsvarende udvikling for sin og deres. For at give et bud på disse spørgsmål har jeg gennemgået et antal tekster fra den ældre nydanske periode. Jeg har udelukkende brugt kilder, der er tilgængelige i elektronisk, søgbar form ${ }^{4}$, hvilket naturligt udgør en be-

\footnotetext{
4 Jeg har brugt følgende databaser til at undersøge den ældre nydanske periode: tekstnet.dk - Tekster fra Danmarks middelalder og renæssance 1100-1550 https://duds.nordisk.ku.dk/tekstresurser/dsst/teksterne/ - Tekstsamlingen i Dansk Sprog- og Stilhistorisk Tekstbase (tekster fra ca. 1425-1676) renæssancesprog.dk - Renæssancens sprog i Danmark (1500-1700) adl.dk - Arkiv for Dansk Litteratur (1700-1900, men enkelte tidligere tekster)
} 
grænsning i forhold til udvalget af materiale og forfattere. Til gengæld gør denne strategi det praktisk muligt at gennemgå store mængder tekst fuldstændigt, frem for at se på mindre uddrag. Denne søgemetode kan ses som et alternativ til excerpering.

\section{1. sig og dem}

\subsection{1. sig/dem i Chr. III's Bibel (1550)}

Den historiske udvikling af sig og dem er senest behandlet både i det ældre sprog og i nyere dialektalt talesprog i Pedersen (2017). På baggrund af Diderichsen (1939) og egne excerperinger beskriver hun hvordan der skete et forholdsvist brat skifte i brugen af sig og dem i skriftsproget efter Reformationen. Før Reformationen, som fx Diderichsens data fra lovene i Figur 1 i (21) viser, var dem langt den hyppigste form med reference til flertalsantecedenter. Efter Reformationen vinder sig hurtigt frem og overtager meget af den brug, som dem ellers har haft. Pedersen (2017: 5-6) foreslår (som Diderichsen 1939: 83) at denne forandring skete på grund af tysk påvirkning, da den tyske pendent sich netop kan henvise både til ental og flertal. At dette skift først sker efter Reformationen, forklarer Pedersen ved et samspil mellem øget sprogkontakt med tysk i lærde kredse og den nye bogtrykkerkunst.

Som et supplement til Pedersen (2017) har jeg foretaget en mindre detailundersøgelse af brugen af sig og dem i Chr. III's Bibel fra 1550, som ifølge Diderichsen og Skautrup skulle afvige noget fra den nye brug af sig og dem, som blev fremherskende efter Reformationen. Diderichsen beskriver at Chr. III's Bibel står »paa det middelalderlige Standpunkt, idet der i al Fald i flere af dens Bøger ... er tydelig Overvægt af dem henvisende til Flertalssubjekt « (Diderichsen 1939: 80). Skautrup gentager denne vurdering og skriver, at praksis med at bruge dem ved henvisning til flertalsantecedent også bruges »overvejende i 1550« (Skautrup 1947: 201). Pedersen (2017: 6) spekulerer over hvorfor denne brug i Chr. III's Bibel ikke har dannet norm i skriftsproget og giver som mulig forklaring, at der er variation i sig/dem-brugen i teksten, som derved ikke har kunnet danne et samlende, normsættende indtryk.

Indeværende undersøgelse nuancerer beskrivelserne fra Diderichsen, Skautrup og Pedersen, da det faktisk ikke lader til at være tilfældet at dem skulle være i tydelig overvægt. I Det Gamle Testamente har jeg gennem- 
gået Første og Anden Mosebog, Første Kongebog samt Jobs bog. I Det Ny Testamente har jeg gennemgået Matthæusevangeliet, Markusevangeliet og Johannes' Åbenbaring. Jeg har benyttet den udgave af Chr. III's Bibel der er tilgængelig i søgbar udgave på tekstnet.dk, Tekster fra Danmarks middelalder og rencessance 1100-1550. Her har jeg søgt efter sig (herunder sig selv) og dem (herunder dem selv) og læst samtlige eksempler for at adskille de refleksive eksempler fra de ikke-refleksive. Resultaterne af undersøgelsen fremgår af (25).

$\begin{array}{ll}\begin{array}{ll}\text { sig med flertals- } \\ \text { antecedent }^{5}\end{array} & \begin{array}{l}\text { dem med flertals- } \\ \text { antecedent }\end{array}\end{array}$

Det Gamle Testamente

$\begin{array}{lcc}\text { 1. Mosebog } & 4 & 24 \\ \text { 2. Mosebog } & 5 & 27 \\ \text { Første Kongebog } & 9 & 13 \\ \text { Jobs Bog } & 21 & 14 \\ \text { Det Ny Testamente } & & \\ \text { Matthæus } & 14 & 22 \\ \text { Markus } & 41 & 2 \\ \text { Johannes' Åbenbaring } & 8 & 2\end{array}$

I Første og Anden Mosebog ses ganske rigtigt den omtalte tydelige overvægt af dem, og det virker måske heller ikke urimeligt derfra at konkludere at det også må være tilfældet for resten af teksten. Denne hypotese kan dog ikke opretholdes. I Det Ny Testamente og i andre bøger i Det Gamle Testamente ses et helt andet billede, nemlig enten at sig og dem er nogenlunde lige hyppigt brugt (som i Matthæus, Første Kongebog og Jobs Bog) eller at sig er den hyppigste form (som i Markus og Johannes' Åbenbaring).

Der er en interessant forskel i hvordan sig og dem bliver brugt i Det Gamle og Det Ny Testamente, også ud over den åbenlyse forskel i hyppighed. I et enkelt tilfælde i Anden Mosebog optræder sig som komple-

\footnotetext{
5 Jeg finder 0 eksempler på sig selv i Det Gamle Testamente og 3 eksempler på dem selv med flertalsantecedent. I Det Ny Testamente finder jeg 4 sig selv med flertalsantecedent og $3 \mathrm{dem}$ selv med flertalsantecedent. I alle andre tilfælde hvor sig eller dem optræder uden selv, ville der heller ikke være et selv i det moderne sprog.
} 
ment til en præposition, (26a), mens det i alle andre tilfælde optræder som et verbalkomplement, (26b-c). I alle fire bøger i Det Gamle Testamente bliver dem brugt både som præpositionskomplement, (27a-b), og som verbalkomplement, (27c-d), om end med verbalkomplementet som den hyppigste kontekst.

(26) a. Oc de $\mathbf{d e}_{1}$ anammede til sig $\mathbf{s i f f}_{1}$ ase al den Løfftning / som Jsraels børn frembare til at gøre den gerning met (2. Mos. 36.3)

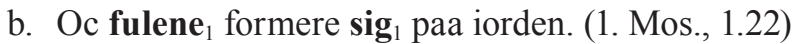

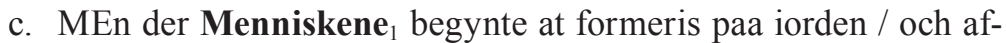
flede $\mathbf{s i g}_{1}$ døtter (1. Mos. 6.1)

(27) a. Jeg haffuer giffuit eder alle Vrter / ath $\mathbf{d e}_{1}$ skulle giffue sæd aff $\mathbf{d e m}_{1}$ offuer all iorden (1. Mos. 1.29)

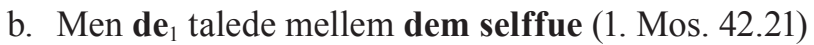

c. Mig tøcte at Solen oc Maanen oc elleffue Stierner $_{1}$ bøyde dem $_{1}$ ned for mig. (1. Mos. 37.9)

d. som vaar alle de $_{1}$ / som met en fri vilie bøde dem selffue $e_{1}$ til oc ginge frem (2. Mos. 36.2)

I Det Ny Testamente er fordelingen anderledes, således at sig i alle tre bøger optræder som præpositionskomplement i $20-30 \%$ af forekomsterne (eksempler på begge former fra alle tre bøger i (28a-h).

(28) a. De daarlige toge deris Lamper / Oc de toge icke Olie met $\mathbf{s i g}_{1}$. (Matt. 25.3)

b. Men Maria Magdalena vaar der / oc den anden Maria / de $\mathbf{d}_{1}$ sette $\mathbf{s i g}_{1}$ tuert offuer fra Graffuen (Matt. 27.61)

c. At $\mathbf{d e}_{1}$ skulde inted bære met sig s $_{1}$ paa veyen / (Mark. 6.8)

d. Och Jhesus kende strax i sin Aand / at $\mathbf{d e}_{1}$ tenckte saa ved sig selff $_{1} /$ (Mark. 2.8)

e. Thi der skulle mange falske Christi ${ }_{1}$ reyse sig s $_{1}$ op / (Mark. 13.22)

f. Oc de $\mathbf{d e}_{1}$ haffde en Konge offuer $\mathbf{s i g}_{1}$ / en Engel aff affgrunden / (Ab. 9.11)

g. Oc Købmendene paa Jorden ${ }_{1}$ skulle græde oc sørge ved sig selff $_{1} /(A b .18 .11)$

h. Oc ieg saa Stole / oc de dette $_{1} \mathbf{s i g}_{1}$ der paa / oc dem bleff Domen giffuen / (Ab. 20.4) 
I Det Ny Testamente bruges dem stadig med både verber og præpositioner, som eksemplerne i (29a-e) viser. Det er værd at bemærke at de sidste to eksempler med dem, (29e-f) også ville være grammatiske i moderne dansk, da der netop i den givne kontekst (med refleksivet i en ikke-finit indlejret sætning og antecedenten i matrixsætningen, ikke-lokal refleksiv) formentlig er valgfrihed mellem sig og dem (jf. Ehlers \& Vikner 2017: 111). Den moderne oversættelse (som er tilgængelig online på bibelselskabet.dk) har sig i stedet for dem i (29f), men stadig dem i (29e).

(29) a. At de de $_{1}$ skulle icke træde dem met deris Føder / Oc vende dem om / oc riffue eder sønder. (Matt. 7.6)

b. Da tenckte de ded $_{1}$ ved dem self $_{1} /$ oc sagde / (Matt. 16.7)

c. At de s $_{1}$ skulde inted bære met sig paa veyen / Vden alene en Staff / ey Taske / ey Brød / ey Pendinge i beltet / Men skulde haffue sko paa / oc icke føre dem 1 i tho Kiortle. (Mark. 6.8)

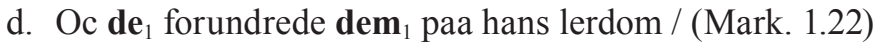

e. Oc de $\mathbf{d e}_{1}$ hørde en stor røst aff Himmelen sige til $\mathbf{d e m}_{1} /$ Stiger hid op. (Ab. 11.12)

f. Oc hans Sønner ginge hen oc giorde Gestebud / huer i sit Huss paa sin dag / oc de $\mathbf{d e}_{1}$ sende hen / oc bade deris tre søster til at æde oc dricke met $\mathbf{d e m}_{1}$. (Job. 1.4)

Jeg opsummerer tallene for sig og dem som henholdsvis komplementer til verber (V-komp) og til præpositioner (P-komp) i (30). Tallene er givet for hver af de fire bøger i Det Gamle Testamente og tre bøger i Det Ny Testamente, som jeg har undersøgt.

\begin{tabular}{|c|c|c|c|c|}
\hline \multirow[b]{2}{*}{ Det Gamle Testamente } & \multicolumn{2}{|c|}{$\begin{array}{l}\text { sig med flertals- } \\
\text { antecedent }\end{array}$} & \multicolumn{2}{|c|}{$\begin{array}{l}\text { dem med flertals- } \\
\text { antecedent }\end{array}$} \\
\hline & V-komp & P-komp & V-komp & P-komp \\
\hline Første Mosebog & 4 & $\mathbf{0}$ & 16 & 8 \\
\hline Anden Mosebog & 4 & 1 & 25 & 2 \\
\hline Første Kongebog & 9 & $\mathbf{0}$ & 11 & 2 \\
\hline Jobs Bog & 21 & $\mathbf{0}$ & 13 & 1 \\
\hline Det Ny Testamente & V-komp & P-komp & V-komp & P-komp \\
\hline Matthæus & 9 & 5 & 18 & 4 \\
\hline Markus & 31 & 10 & 2 & 0 \\
\hline Johannes’ Åbenbaring & 6 & 2 & 1 & 1 \\
\hline
\end{tabular}


Den største forskel ligger i det domæne, som sig bliver brugt i i de to testamenter. I Det Gamle Testamente optræder sig næsten udelukkende som verbalkomplement: Det eneste eksempel på sig som komplement til en præposition er fra Anden Mosebog, hvor præpositionsforbindelsen med sig optræder efter et verbum af tysk oprindelse (annamme, ODS), som måske ud fra et tysk oversætterforlag kan have ansporet til at anvende sig. Denne begrænsning af sig til verbalkomplementer gør sig gældende også i Første Kongebog og Jobs Bog hvor sig med flertalsantecedent er enten lige så hyppig eller mere hyppig end dem med flertalsantecedent. I de tre bøger fra Det Ny Testamente, som jeg har undersøgt, er sig med flertalsantecedent samlet set langt hyppigere end dem. Samtidig er anvendelsen væsensforskellig, da sig i Det Ny Testamente både optræder som verbalkomplement og præpositionskomplement, og endda med en ganske høj andel af præpositionskomplementer. Dem fortsætter med at kunne anvendes både som verbalkomplement og præpositionskomplement, om end noget mindre hyppigt end i bøgerne i Det Gamle Testamente.

Det er svært at give en sikker forklaring på forskellen i refleksivbrugen mellem de to testamenter, men mit bud er at Det Gamle Testamente netop afspejler en ældre brug eller en overgangsbrug, som både viser sig i lavere andel af sig og i at sig er begrænset til verbalkomplementer. Det Ny Testamente kan så tilsvarende repræsentere et senere stadie i udviklingen, hvor sig har indtaget begge domæner og dem er blevet trængt ud. Måske har redaktørerne af de enkelte bøger i forskellig grad adopteret den nye refleksivbrug og indført den tilsvarende. I det senere standardsprog mister dem med flertalsantecedent helt muligheden for at optræde som verbalkomplement, jf. ugrammatikaliteten af en sætning som Børnene hygger dem $_{1}$. I domænet præpositionskomplement mener jeg, at der stadig i det moderne sprog ses en vis grad af valgfrihed mellem sig og dem, eksemplificeret ved de parallelle eksempler i (31a-b). Som nævnt tidligere i teksten er der også valgfrihed mellem sig og dem i ikke-lokale kontekster. Dem med flertalsantecedent er altså ikke fuldstændig fortrængt, men bare stærkt begrænset i sine anvendelsesmuligheder.

(31) a. Så svømmede de ind mod land, mens $\mathbf{d e}_{1}$ trak jollen efter dem $_{1}$ (KorpusDK)

b. Scrooge kom i tanke om at have hørt, at spøgelser ${ }_{1}$ i hjemsøgte huse ofte trak tunge lænker efter $\mathbf{s i g}_{1}$ (KorpusDK) 


\subsection{2. sig/dem i dialekterne}

Diderichsen (1939: 67) skriver selv om sproget i sin samtid at »i Pluralis har Dialekterne og det ældre [københavnske?] eller lavere Talesprog i al fald ofte dem for sig og normalt deres for sin, mens Skriftsprogsnormen og Grammatikerne kræver henh. sig og deres«. Her understøttes Diderichsens betragtninger af optegnelser fra de forskellige tilgængelige dialektbeskrivelser, som er nogenlunde samtidige. I den lille grammatik, der tilhører Ordbog over Fjoldemålet (Bjerrum og Bjerrum 1974: 24), beskrives det at sig bruges refleksivt med entalsantecedenter og dem bruges refleksivt med flertalsantecedenter. I Jysk Ordbog fremgår det tilsvarende, at dem er flertalsformen svarende til entalsformen sig. Ordbogens materiale dækker i princippet perioden fra 1700 til 1930, men langt det meste af materialet beskriver dialekterne, som de blev talt mellem 1850 og 1900. Ordbogen giver de to eksempler i (32). I (32b) er antecedenten fløde som i standarddansk er et entalsord. I de jyske dialekter her falder fløde ind under kategorien stof-pluralis (Arboe 2016: 106) hvor visse, typisk flydende, kollektiver ( $g r ø d$, suppe, kål blandt andet) opfører sig som flertalsord. Også slaw er et flertalsord.

(32) a. a wo jo et' o de Slaw 1 , dæ ku fjedt' dæm 1 igjæm'mel Jeg var jo ikke af den slags, der kunne fedte sig igennem (og derved opnå fordele).

b. om 'somə kun ə 'flø $\boldsymbol{\sigma}_{1}$ blyw 'su åw dæm 'sjæl

Om sommeren kunne fløden blive sur af sig selv.

I Ømålsordbogen (1996: 30) fremgår det, at dem er almindelig i refleksiv anvendelse, og den giver blandt andet eksemplerne i (33). Redaktionerne på både Jysk Ordbog og Ømålsordbogen er ikke nået til sig endnu, så jeg må begrænse mig til dem og konstatere at dem både i jysk og i ømålene lader til at have været en almindelig refleksiv form.

(33) a. for så forsluger $\mathbf{d e}_{1} \mathbf{d e m}_{1}$ jo (om heste, der ikke arbejder) (Nordsjælland)

b. $\mathbf{d e}_{1}$ tog godt til $\mathbf{d e m}_{1}$ (dvs. spiste meget) (Nordsjælland)

c. $\mathbf{d e}_{1}$ sidder og keder $\mathbf{d e m}_{1}$ og har ikke noget at tage $\mathbf{d e m}_{1}$ til (Falster)

d. $\quad$ de $_{1}$ drak dem $_{1}$ fulde (Tåsinge) 
Jul Nielsen (1986: 44) behandler ikke sig i mange detaljer, men bemærker dog »at brugen af dem i stedet for rigsmålets sig ved henvisning til pluralissubjekt (hvilket er hyppigt forekommende, men ikke enerådende) er fælles for jysk og en række andre dialekter og talesprogsvarieteter (incl. lidt ældre sprog)«. De informanter, der ligger til grund for en del af Jul Nielsens undersøgelse, er for størstedelens vedkommende født mellem 1880 og 1920, og resten af undersøgelsen bygger på grammatikker og dialektoptegnelser af talere, der er endnu ældre. I Ordbog over det danske Sprog, som dækker dansk mellem 1700 og 1950, skrives der, at dem anvendes refleksivt i daglig tale, især i jysk, når der henvises til flertalsord.

Pedersen (2017) undersøger udviklingen i dem og sig i dialekterne nærmere, og jeg refererer kort hendes konklusioner. I lavkøbenhavnsk talesprog har man kunnet høre dem brugt refleksivt frem til 1950'erne, hvorimod sig vil have været den eneste mulige form i det højsociale københavnske på det tidspunkt. På baggrund af et lille tekstmateriale konstateres det, at en tilsvarende udvikling kan ses i tre provinsbyer på Fyn: Dem forsvinder tidligst i Odense, den store provinsby, og senere i de mindre byer, på samme måde som det forsvinder tidligst blandt de højsociale københavnere med længere skolegang. Østjysk har formentlig haft det refleksive dem frem til 1900-tallet hvorefter sig begyndte at vinde frem. Det sker i hvert fald i en vis udstrækning i vestjysk. Sønderjysk har muligvis bevaret det refleksive dem lidt længere. De fynske dialekter har formentlig indført sig lidt tidligere end de jyske, og Pedersen (2017: 24) konkluderer at dem har været den mest brugte form dér frem til 1850'erne. Tilsvarende finder hun for de sjællandske dialekter først belæg på sig med flertalsantecedent i den anden halvdel af 1800-tallet. På baggrund af et lille båndmateriale og et større ordbogsmanuskript finder Pedersen at dem var enerådende på Bornholm i hvert fald frem til 1930'erne.

\section{2. $\sin$ og deres}

Den historiske udvikling i brugen af sin og deres behandles ikke i Pedersen (2017), der fokuserer på sig og dem. Diderichsen har en større eksempelsamling med enkelte eksempler på sin med flertalsantecedent fra et stort antal forfattere og tekster, og skriver overordnet at sin med flertalsantecedent optræder »lejlighedsvis (som Regel sikkert kun ved Lapsus...)« (Diderichsen 1939: 68-69). Eksempelsamlingen 
viser at $\sin$ er blevet brugt med flertalsantecedent, men ikke i hvor høj grad. Jeg har undersøgt brugen af sin og deres i et udvalg af ældre og yngre nydanske kilder i en bestræbelse på at komplementere Diderichsens eksempelsamling og for at kunne give et bud på netop i hvor høj grad $\sin$ er blevet brugt med flertalsantecedent i den nydanske periode.

Jeg har undersøgt brugen af sin og deres i Chr. Pedersens En nøttelig Legebog fra 1533 og fundet to eksempler på sin med flertalsantecedent og omkring 40 eksempler på deres. De to eksempler med sin er gengivet i (34).

(34) a. Man skall oc giffue de $\operatorname{siwge}_{1}$ Saffran i $\sin _{1}$ mad thi det gør at soffue

Man skal også give de syge safran i deres mad, for det hjoelper dem med at sove

b. De som haffue denne brøst, $\mathbf{d e}_{1}$ skulle gerne æde Agerhønse ægh, Eller oc støde dem raa, och smørge sig met dem paa $\sin _{1}$ lønlige ting

De som har denne sygdom, de skal spise agerhønseag, eller også skal de slå ceggene ud rå og smøre sig med dem på deres lønlige ting (dvs. kønsorgan)

I (34b) ses et sig med henvisning til samme flertalssubjekt som sin henviser til og det kan tænkes at denne foregående refleksiv har ansporet til en ægte refleksivform i possessiven også.

I Paul Helgesens Erasmus-oversættelse (1534) har jeg undersøgt den første tredjedel af teksten, og her finder jeg et enkelt eksempel på sin brugt med flertalsantecedent: bonder ${ }_{1}$ bruge icke thenom wden till sitt ${ }_{1}$ egett gaffn.

I Hans Tausens Postil, som jeg har læst uddrag af (Vinterdelen, juleevangeliet fra 1539), er der ingen eksempler på sin med flertalsantecedent og ca. 7 eksempler på deres med flertalsantecedent. I Kirkeordinansen (1539), formentlig overvejende oversat af Peder Palladius men med andre redaktører og forfattere inde over, er der i høj grad variation i brugen. Der finder jeg mindst 16 eksempler på sin med flertalsantecedent (herunder bøjningsvarianterne sit og sine og de ortografiske varianter syn, syt $(t)$ og syne) og omkring 40 deris. Tre eksempler med $\sin$ fra Kirkeordinansen er givet i (35). 
(35) a. hoss dennom 1 som ere dømde til døde oc skulle affliffues for sine $_{1}$ misgierninger/

b. at $\mathbf{d e}_{1}$ med rett alworlighed bekiende $\| \sin _{1}$ tro/ oc begere saa sacramentet/

c. Des ligeste skulle oc scholemesterne (...) giffue forældrene i rett tromol tilkiende/ huilcke $\mathbf{a}_{1}$ aff $\mathbf{s y n}_{1}$ studeren intet siunes at bliffue forbedrede/

Diderichsen har gennemset de første 50 sider af Palladius' Sct. Peders Skib og finder ingen eksempler på sin med flertalsantecedent, over for ca. 21 deres (Diderichsen 1939: 79). Givet brugen af sin og deres i Kirkeordinansen, ville jeg forvente at se flere $\sin$ med flertalsantecedent i Palladius' andre tekster. At det ikke er tilfældet, i hvert fald i den ene prædiken undersøgt af Diderichsen, kunne tyde på, at Palladius ikke har haft sin med flertalsantecedent som en del af sin grammatik, og at de sin, der optræder med flertalsantecedent i Kirkeordinansen, kunne være påvirket af tysk eller af andre redaktørers grammatik.

I Første Mosebog og Matthæusevangeliet i Chr. III's Bibel finder jeg stort set ikke nogen variation i brugen af sin og deres med flertalsantecedent, i modsætning til i brugen af sig og dem som beskrevet i afsnit 3.1.1. I Første Mosebog er der en enkelt sætning med to sin med flertalsantecedent over for 44 deres. I Matthæusevangeliet er der et enkelt eksempel på $\sin$ med flertalsantecedent over for 37 deres. Begge de nævnte eksempler er vist i (36).

(36) a. Och Gud skabte diur paa Jorden / huert effter sin art / oc fä effter $\sin _{1}$ art / och alle haande orme paa Jorden $/$ effter $\sin _{2}$ art. Oc Gud saa at det vaar got (1. Mos. 1.25)

b. Der hand saa nu mange Phariseer oc Saduceer ${ }_{1}$ komme til $\sin _{1}$ Daab / sagde hand til dem (Matt. 3.7)

I Anders Sørensen Vedels Predicken over Kansler Friis (1571) finder jeg ingen sin med flertalsantecedent efter en søgning i de første 48 sider, og deres er den eneste anvendte form. I Niels Hemmingsens Om Ecteskab (1572) har jeg søgt på sin (og sit) i den første halvdel af bogen og finder ingen eksempler med flertalsantecedent. Jeg har læst kortere udsnit for at bekræfte, at deris bliver brugt i stedet.

Leonora Christine (1621-1698) bruger udelukkende deres eller derres - og ikke $\sin$ - med reference til flertalsantecedenter i det uddrag fra 
Jammers Minde, som jeg har undersøgt (side 94-184 af teksten på adl. $\mathrm{dk})$.

Jeg har gennemset alle eksempler på sin og deres i de tekster af salmedigteren Thomas Kingo (1634-1703), der er tilgængelige på renæssancesprog.dk. ${ }^{6}$ Kingo har påfaldende mange $\sin$ med flertalsantecedent, og i næsten samtlige tekster optræder $\sin$ mindst lige så hyppigt som deres med flertalsantecedent. Det er nærliggende at forestille sig, at rim og rytme kan have spillet ind i forhold til valg af refleksiv form, og jeg giver et udvalg af repræsentative eksempler i (37).

(37) a. Alle hâr sit ${ }_{1}$, Stort eller Lit! (Aandelig Siunge-Koor (1681))

b. Deyligste Roser hâr stindeste Toorne, Skiønneste Blomster ${ }_{1}$ $\sin _{1}$ tærende Gift, (Aandelig Siunge-Koor (1681))

c. Huor deris Hænder de $_{1}$ til nogen Gierning sætter, (Kroneborgs Korte Beskrifvelse)

d. Gud trøste dem $_{1}$ der ere nu I deris ${ }_{1}$ Døds minut, (Siunge-Koor (1674))

e. Og de de $_{1}$ med deres ${ }_{1}$ Blood $\sin _{1}$ troskab vidne maa. (Hosianna)

I (37a) rimer sit på Lit og i (37b) ville et deres bryde rytmen. Jeg finder ingen eksempler på sine, så deres bliver brugt alle steder, hvor possessum er i flertal, fx i (37c), men deres optræder også med entalskomplementer, (37d). I (37e) optræder både sin og deres i samme sætning og med henvisning til samme flertalsantecedent.

Kingo har måske haft en grammatik, hvor både $\sin$ og deres kunne anvendes med flertalsantecedent. Jeg finder mindst 20 eksempler på sin med flertalsantecedent (og en lille håndfuld hvor det ikke er helt klart, hvad antecedenten er) og samme antal deres med flertalsantecedent. Der er for mange eksempler på sin til, at det kan være ren lapsus, og samtidig er det tydeligt, at Kingo bruger sin og deres aktivt forskelligt i sine tekster, således at sin optræder, hvor der er behov for et etstavelsesord og deres, hvor der er behov for et tostavelsesord. Hvis sin med flertalsantecedent ikke var en del af hans grammatik, kunne han vel i princippet bare have

\footnotetext{
6 Aandelig Siunge-Koor (1681), Christian Vs første Ledings-Tog (1676), De Fattiges udj Odensee Hospital (1682), Hosianna (1671), Kroneborgs Korte Beskrifvelse (1672), Mølle-borups Velkom (1675), Paa-Skrifter udi Niels Juels Epitaphio i Holmens kirke, Samtale med Rygtet (1699), Siunge-Koor (1674), Til... Brigitte Baltzlow (1689), Vinterparten af Danmarks og Norges forordnede Psalmebog (1689).
} 
skrevet sine vers anderledes og kun brugt deres. Kingo er den eneste af de undersøgte forfattere, der skriver på vers, og det må være et åbent spørgsmål, om andre digtere også kan have brugt sin med flertalsantecedent efter behov.

Holberg (1684-1754) blev født i Bergen, og må nødvendigvis have hørt mere norsk i sine tidlige år end mange andre danske forfattere. Af samme grund kunne man forestille sig at Holberg havde en grammatik, der fulgte den norske brug af $\sin$ med flertalsantecedent. Som Diderichsen (1939: 68, fn. 2) også bemærker, er dette dog ikke tilfældet. Skautrup (1953: 28, 37) skriver til dels samlende at Holberg bruger "sine for deres: (de) tugtede sine Fiender... mange forlode sine Booliger « (Skautrup 1953: 28), men også senere modsat at Holberg faktisk »undgår [...] norvagismerne sin og sine, om end exempler kan findes « (Skautrup 1953: 37). Den sidste beskrivelse går igen i Holberg-ordbogen, hvor det også fremgår, at deres er den mest almindelige form. Denne vurdering understøttes af en egentlig optælling i tre Holberg-tekster. I Naturens og Folke-rettens Kundskab (adl.dk, s. 51-141) finder jeg et enkelt eksempel på sin med flertalsantecedent (gengivet i (38a)) over for 43 deres. I Mascarade finder jeg fire $\sin ,(38 \mathrm{~b}-\mathrm{d})$, og otte (måske ni) deres med flertalsantecedent. I Jean de France finder jeg ét sin med flertalsantecedent, (38e), over for 13 deres.

(38) a. thi her contribuere begge $e_{1}$ noget i Gierningen til $\sin _{1}$ Næstes Vanære

(Naturens og Folke-rettens Kundskab s. 105)

b. $\quad$ De $_{1}$ demaskerer sig begge, tales ved, og gir hinanden sine $e_{1}$ Ringe.

(Mascarade s. 191, regibemærkning)

c. Unge Folk 1 har sine 1 Tidsfordrive, og gamle Folk sine $_{2}$. (Mascarade s. 198, replik)

d. Men Hr. Jeronimus, I kand lære af denne Historie, at Mascarader $_{1}$ har ogsaa $\sin _{1}$ Nytte (Mascarade s. 238, replik)

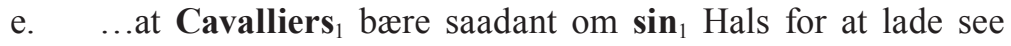
Estime for de Damer, (Jean de France s. 189)

Holberg har altså ganske vist en del eksempler på sin med flertalsantecedent, men deres er den hyppigste form.

Johannes Ewald (1743-1781) bruger udelukkende deres, og aldrig sin, med reference til flertalsantecedent i De Fremmede, hvor jeg har under- 
søgt brugen på de første 50 sider i udgaven på adl.dk. Det samme er tilfældet for Fiskerne (1969-udgaven på adl.dk).

Jeg har gennemset de første 60 sider af Jens Baggesens (1764-1826) Labyrinten (1971-udgaven på adl.dk), og finder her ingen eksempler på sin med flertalsantecedent. I Grundtvigs Nordens Mytologi (1808) finder jeg et enkelt eksempel på sin med flertalsantecedent, gengivet i (39).

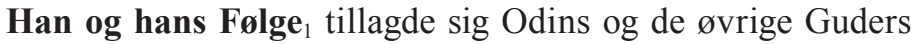
Navne, eller gave maaske Guderne sine $\mathbf{s}_{1}$ og vilde holdes for deres Repræsentantere paa Jorden.

Jeg har gennemset fire tekster af H.C. Andersen og fundet to eksempler på sin med flertalsantecedent, som er gengivet i (40), men altså langt overvejende deres. Udover de to tekster med de to eksempler har jeg gennemlæst de første 80 sider af Skyggebilleder og Første og Andet Hefte af Eventyr, fortalte for Børn.

(40) a. Der gives Mennesker ${ }_{1}$, der ret kunne udtale for Andre sine Lidelser og Elendigheder (Fodreise s. 27)

b. Luften var saa tør, at Mund og Hals Habte $_{1} \sin _{1}$ naturlige Fugtighed (I Spanien s. 47)

Igennem hele den nydanske periode, og antageligt helt tilbage til de ældste håndskrifter, er deres den hyppigste form. Der kan findes sin med flertalsantecedent i mange forfatterskaber og mange teksttyper gennem hele perioden og også forfattere som Thomas Kingo, som muligvis har haft sin og deres som varianter i deres grammatik. Der ses ingen tegn på en udvikling tilsvarende ændringerne i brugen af sig og dem fra Reformationen og frem, og som er kulmineret $i$ at dem $i$ langt det fleste tilfælde ikke længere kan bruges som refleksiv form. Det er dog også netop, hvad vi ville forvente, hvis ændringen i sig og dem skete som konsekvens af kraftig sproglig påvirkning fra tysk: Tysk har $i h r$, som bruges med henvisning til flertalsantecedenter og svarer til det danske deres, da $i h r$ kan bruges både refleksivt og ikke-refleksivt. Der er altså ingen tysk form, der ville kunne påvirke i retning af hyppigere brug af sin med flertalsantecedent, hvorimod det tyske sich netop ville anspore til hyppigere brug af sig. Tysk påvirkning i domænet possessiver ville snarere anspore til at understøtte deres og fortrænge tendenser til at bruge sin med flertalsantecedent. 


\section{Refleksivt dem i moderne dansk}

På Københavns Universitet har Sprogforandringscentret en stor database med talesprog fra 1970'erne til i dag, LANCHART-korpusset (se fx Gregersen 2009 for flere detaljer om projektet). Jeg har undersøgt brugen af refleksivt dem i LANCHART-korpusset for at give et bud på, hvorvidt det kan siges stadig at eksistere i talesproget $\mathrm{i}$ dag. Undersøgelsen i dette afsnit er væsensforskellig fra fx Diderichsens da den baserer sig på rent kvantitativt materiale, hvorimod den førnævnte undersøgelse $\mathrm{i}$ en vis grad bygger på kvalitativ excerpering af tekster. En faldgrube ved den mere kvalitative tilgang er risikoen for at det markerede inkluderes på bekostning af det umarkerede, selvom man som excerpist gør sit bedste for at undgå det.

Til undersøgelsen her har jeg gennemlæst omtrent 15.000 sætninger i LANCHART med formatet [ $V \mathrm{dem}$ ], altså sætninger med et verbum efterfulgt af $\mathrm{dem}$. Jeg har valgt at undersøge denne undergruppe af alle mulige dem i LANCHART for mest muligt at nedbringe mængden af irrelevante resultater - resultater med ikke-refleksivt dem, som alligevel udgør langt størstedelen af mit data. Med denne søgning udelukker jeg desværre mulige eksempler på dem som komplement til en præposition, så de må forsøges inkluderet $\mathrm{i}$ en eventuel senere undersøgelse. Jeg ville forvente en højere andel af refleksivt dem som præpositionskomplement, men jeg har ikke data til at be- eller afkræfte denne formodning. Jeg har desuden efter søgningen udelukket 1286 sætninger som stammer fra Danske Stemmer i Amerika-projektet (se fx Kühl 2014) om talesprog fra udvandrede danskere og deres efterkommere. Disse talere har en noget højere andel af refleksivt dem (14 eksempler ud af 1286 sætninger, eller $1,1 \%$, hvilket er omtrent ti gange så mange som i resten af det undersøgte materiale). Samtidig er der mange faktorer som gør disse talere anderledes, ikke mindst er de alle en hel del ældre end resten af talerne i materialet og har derudover været udsat for massiv påvirkning fra andre sprog end dansk. Uden disse 1286 sætninger består mit LANCHART-materiale af 13.867 sætninger.

Det refleksive dem i LANCHART er meget lidt hyppig: Ud af 13.867 fandt jeg 18 eksempler på refleksivt dem, hvilket svarer til en forsvindende lille andel på $0,13 \%$. Jeg giver et udpluk af resultaterne i (41).

(41) a. de sad og havde deres øh frokost og de havde deres øh øl og hvad $\mathbf{d e}_{1}$ nu hyggede $\mathbf{d e m}_{1}$ med ikke 
(LANCHART, kvinde, arbejderklasse, født 1928, BYSOC0 1987, København)

b. nogle lærlinge de kan få firmabil og andre lærlinge eller voksenlærlinge de $\mathbf{d e}_{1}$ må klare dem selv ${ }_{1}^{7}$

(LANCHART, mand, arbejderklasse, født 1989, Familiel 2006, Vinderup)

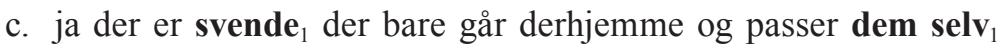

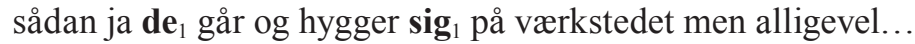

(samme taler som b.)

d. jamen jeg tror da de festede simpelthen til langt ud på natten og jeg tror $\mathbf{d e}_{1}$ hyggede $\mathbf{d e m}_{1}$

(LANCHART, kvinde, arbejderklasse, født 1965,

Familie1 2006, Vinderup)

e. $i$ et hjem der hører der børn til for det var derfor folk de de $_{1}$ giftede dem $_{1}$

(LANCHART, mand, født 1939, Familie1 2007, Vinderup)

f. hvor man havde indkaldt forskellige uddannelsesinstitutioner hvor $\mathbf{d e}_{1}$ skulle komme og præsentere dem selv $\mathbf{v}_{1}$

(LANCHART, kvinde, født 1968, Odder2 2008)

g. nej men det må $\mathbf{d e}_{1}$ jo bukke dem$_{1}$ for jo

(LANCHART, mand, arbejderklasse, født 1970, Tinglev2 2010)

h. og det ville de $_{1}$ egentlig godt øh frasige dem $_{1}$ på daværende tidspunkt

(LANCHART, kvinde, arbejderklasse, født 1964,

Vinderup2 2006)

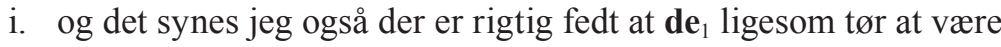
dem selv ${ }_{1}$ og sige jeg er da ligeglad med alle jer andre

(LANCHART, kvinde, arbejderklasse, født 1991,

Vinderup3 2006)

Én taler, en mand født i 1939, står alene for seks af eksemplerne, og det virker ikke urimeligt at sige at vi nok her har at gøre med én der primært har refleksivt dem. Taleren bruger ganske vist refleksivt sig, men kun med entalsantecedenter (»)jeg tror ikke det har ændret sig ret meget () . I flere af de andre taleres tilfælde kunne man forestille sig at de enkelte eksempler på refleksivt dem nærmere er en marginal variant. Fx

7 Den anonyme bedømmer foreslår at der her nærmere er tale om klare sig (dem) med selv som modifikator frem for klare sig selv (dem selv). 
bruger taleren i eksempel (41b), en mand født i 1989, sig med både flertalsantecedent (»så hygger de sig med det«) og entalsantecedent (»men han har altid interesseret sig for det«) i tilgift til de to eksempler med refleksivt dem. Det refleksive dem kan findes her og der hos både ældre og yngre talere, men det er bestemt mest hyppigt blandt de ældste talere i materialet. De undersøgte ældre grammatikker fra det 20. århundrede nævner da også alle sammen at refleksivt dem er et talesprogstræk eller et dialekttræk, og i et Danmark hvor dialekterne i høj grad er blevet trængt tilbage i det seneste århundrede (se fx Dialekter - sidste udkald? (2002)), er det formentlig ikke så mærkeligt at det dialektale refleksive dem også er det.

Det refleksive dem (selv) er dog ikke mere marginalt end at der kan findes adskillige eksempler på refleksivt dem selv i KorpusDK. I Sørensen et al. (2020) undersøger forfatterne brugen af ham selv, hende selv og dem selv i KorpusDK og finder i denne forbindelse at en langt højere andel af eksemplerne med dem selv (12,8\%) end af ham selv, og hende selv (hhv. 1,1 \% og 2,3\%) optræder i tilfælde, hvor man præskriptivt ville have forventet sig selv. Eksemplerne i (42) nedenfor illustrerer nogle af disse tilfælde, alle fra KorpusDK. I langt størstedelen af disse eksempler optræder dem selv som komplement til en præposition (i 64 tilfælde) og sjældnere som komplement til et verbum (i 11 tilfælde).

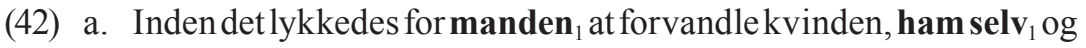
virksomheden til et flammehav ...

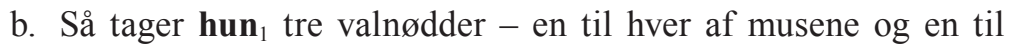
hende selv $v_{1}$.

c. Men hvordan har du tjent alle de der penge? De $\mathbf{D}_{1}$ er kommet af dem selv ${ }_{1}$ !

d. Både Bodil Lous og Johnny O’Hagan 1 lærer tydeligvis noget om dem selv s..

e. Da en universitetslærer bad de studerende sm $_{1}$ at skrive en stil om dem selv , blev hun chokeret ...

f. ... og tre medlemmer af forbundets ledelse $e_{1}$ har udpeget dem $\mathbf{s e l v}_{1}$ til at rådgive holdet frem til kampen mod Sydafrika.

Denne overrepræsentation af dem selv $\mathrm{i}$ forhold til ham/hende selv $\mathrm{i}$ disse 'fejl'-kontekster tolker jeg som en rest fra det ældre sprogs hyppigere anvendelse af det refleksive dem. 
Det refleksive dem forekommer umiddelbart stadig produktivt, om end sjældent, i moderne standarddansk og kun i begrænsede kontekster. Herunder ikke-lokalt (se eksempel (24d), gentaget her som (43a) med (43b) som et tilsvarende eksempel på et ikke-lokalt refleksiv med flertalsantecedent, sig i stedet for dem) og i visse præpositionsforbindelser (se eksemplerne i (31), gentaget her som (43c-d)) som alternativ til sig.

(43) a. De $\mathbf{D}_{1}$ var klædt som forretningsmænd og bad mig køre dem $_{1}$ til South Bronx. (KorpusDK)

b. De 1 havde store marker og karle og piger til at arbejde for $\mathbf{s i g}_{1}$. (KorpusDK)

c. Så svømmede de ind mod land, mens de $\mathbf{d e}_{1}$ trak jollen efter $\mathbf{d e m}_{1}$. (KorpusDK)

d. Scrooge kom i tanke om at have hørt, at spøgelser ${ }_{1}$ i hjemsøgte huse ofte trak tunge lænker efter $\mathbf{s i g}_{1}$. (KorpusDK)

Dem selv (jf. (37)) optræder tilsvarende for nogle talere som alternativ til sig selv. Jeg formoder at lokalt bundet dem som verbalkomplement (som i (4la, d-e, g-h)) er et dialektalt talesprogstræk, som ganske vist stadig optræder hyppigt nok til at blive registreret $i$ et korpus som LANCHART, men alligevel må siges at være stort set forsvundet fra sproget siden 1900-tallet.

\section{Konklusion}

I moderne dansk er der en forskel mellem refleksiverne sin og sig. Normalt tillader sin ikke flertalsantecedenter, hvorimod sig kan bruges både med entals- og flertalsantecedenter. Det er derfor, vi siger, at forceldrene elsker deres børn (ikke sine børn), men forceldrene glader sig til weekenden (ikke glceder dem). Denne forskel på sin og sig er en forholdsvis moderne forskel, da man for bare hundrede år siden stadig kunne høre talere sige at de øvede dem (i betydningen de øvede sig), men hun øvede sig. I det lidt ældre sprog har ikke bare sin, men også sig altså været anvendt primært med entalsantecedenter.

I det dansk som findes i runeindskrifter fra omkring år 1000, bliver sin brugt med både entals- og flertalsantecedenter. Dette er i overensstemmelse med brugen af sin i fællesgermansk og urnordisk. Det samme ville 
formentlig gælde sig, men det tilgængelige datamateriale er for småt til at det indeholder nogen eksempler på sig med flertalsantecedent.

Et par århundreder senere, i landskabslovene fra 1200-tallet, har sproget ændret sig. Sin og sig bliver primært brugt med entalsantecedenter og deres og dem bliver brugt som refleksiver med flertalsantecedenter. Dette er gennemgående tilfældet for de vestdanske love, mens der i Skånske Lov stadig bliver brugt sig også med flertalsantecedenter. Den refleksive brug af sin og sig med entalsantecedenter og deres og dem med flertalsantecedenter holder formentlig ved i talesproget helt frem til det 20. århundrede, mens sig efter Reformationen bliver den hyppigste form i skriftsproget. Deres er gennem hele perioden den hyppigste form, mens sin optræder sporadisk med flertalsantecedent hos mange af de undersøgte forfattere. Thomas Kingo er en påfaldende undtagelse hvor sin og deres optræder nogenlunde lige hyppigt med flertalsantecedent. Kingo er digter og det er muligt at det spiller en rolle for brugen. Måske kan et fast formsprog anspore til hyppigere brug af sin med flertalsantecedent - også for andre talere. For moderne dansk viser data fra LANCHART at den refleksive brug af dem stort set er forsvundet fra sproget, således at sig nu bruges både med entals- og flertalsantecedenter. For sin er langt den hyppigste brug stadig at $\sin$ ikke tillader flertalsantecedenter. 


\section{Litteratur}

Arkiv for dansk litteratur, adl.dk (tilgået 16. december 2019).

Arboe, Torben: Gender and number peculiarities of uncountable nouns in Jutlandic (Western Danish), i: Sten Vikner, Henrik Jørgensen og Elly van Gelderen (red.): Let us have articles betwixt us -Papers in Historical and Comparative Linguistics in Honour of Johanna L. Wood, s. 99-110. Aarhus: Aarhus Universitet 2016.

Bjerrum, Marie og Anders Bjerrum: Ordbog over Fjoldemålet, 1. København: Akademisk Forlag 1974.

Brandt, Søren: Heteronomous text elements, i: Acta Linguistica Hafniensia 33(1), s. 109-175. København 2001.

Brøndum-Nielsen, Johs.: Gammeldansk Grammatik i sproghistorisk Fremstilling V. København: J. H. Schultz Forlag og Akademisk Forlag 1965.

Bibelen online, https://www.bibelselskabet.dk/brugbibelen/bibelenonline. Det Danske Bibelselskab.

Bibelen i autoriseret oversættelse. København: Det Danske Bibelselskab 1992.

Danske Runeindskrifter, http://runer.ku.dk (tilgået 2. december 2019).

Dansk Sprog- og Stilhistorisk Tekstbase, https://uds.nordisk.ku.dk/tekstresurser/dsst/teksterne/ (tilgået 16. december 2019).

Dialekter - sidste udkald? Modersmål-Selskabets Årbog. 2002.

Diderichsen, Paul: Om Pronominerne sig og sin, i: Acta philologica Scandinavica 13, s. 1-95. København 1939.

Ehlers, Katrine Rosendal: »Sig« vs. »dem«, »sin« vs. »deres« - Number sensitive reflexive pronouns and language change in Danish. Ph.d.-afhandling. Aarhus: Aarhus Universitet (under forberedelse).

Ehlers, Katrine Rosendal og Sten Vikner: Sig, sig selv og KorpusDK - hvorfor det er svært både at skælde sig ud og at skille sig selv ud, i: MUDS $16-16$. Møde om Udforskningen af Dansk Sprog, s. 91-120. Aarhus: Aarhus Universitet 2017.

Falk, Hjalmar og Alf Torp: Dansk-Norskens syntax i historisk fremstilling. Kristiania 1900.

Frederiksen, Britta Olrik: Gammeldansk, i: Hjorth, Ebba. m.fl. (red.): Dansk Sproghistorie 3, s. 41-72. København: Det Danske Sprog- og Litteraturselskab 2019.

Gregersen, Frans: The data and design of the LANCHART study, i: Acta Linguistica Hafniensia 41(1), s. 3-29. København 2009.

Hansen, Erik og Lars Heltoft: Grammatik over det danske sprog. Bind 1-3. København: Det Danske Sprog- og Litteraturselskab 2011.

Hinchliffe, Ian og Philip Holmes: Basic Swedish. London: Routledge 2018.

Holmes, Philip og Hans-Olav Enger: Norwegian: A Comprehensive Grammar. London: Routledge 2018.

Hvilshøj, Ulrik: Om sig og sig selv: medium og refleksiv i dansk, i: Nydanske Sprogstudier 26/27, s. 11-34. København 2000. 
Institut for Dansk Dialektforskning, Københavns Universitet: Ømålsordbogen, bind 3: Dagmeje-fald. København: C.A. Reitzel 1996.

Jensen, Eva Skafte: Selv-studier, i: Ny forskning i grammatik 17, s. 47-65. Odense: Syddansk Universitet 2010.

Juel Jensen, Torben: Refleksivt anvendte pronominer i moderne dansk, i: $N y$ forskning i grammatik 16, s. 131-151. Odense: Syddansk Universitet 2009.

Jul Nielsen, Bent: Om pronominet sin i jysk, i: Danske folkemaal 28, s. 41-101. København 1986.

Jysk Ordbog, www.jyskordbog.dk/.

Jørgensen, Bent: Sproghistoriske perioder, i: Hjorth, Ebba. m.fl. (red.): Dansk Sproghistorie 1, s. 79-83. København: Det Danske Sprog- og Litteraturselskab 2016.

Kroman, Erik: Danmarks Gamle Love paa Nutidsdansk, bind 1. København: G. E. C. Gads Forlag 1945.

Kühl, Karoline: Det er easy at tale engelsk også: Amerikadansk i 1960'erne og 1970'erne, i: Nydanske Sprogstudier 47, s. 39-64. København 2014.

Mikkelsen, Kristian: Dansk ordføjningslaere med sproghistoriske tillag: Håndbog for viderekomne og laerere. København: Lehmann \& Stage 1911.

Ordbog over det danske Sprog, https://ordnet.dk/ods/forside.

Pedersen, Karen Margrethe: Refleksivt sig/dem - varianter gennem 800 år. Danske talesprog 17, s. 1-43. København 2017.

Rencessancens Sprog i Danmark, renæssancesprog.dk (tilgået 16. december 2019).

Skautrup, Peter: Det Danske Sprogs Historie II. København: Gyldendal 1947.

Skautrup, Peter: Det Danske Sprogs Historie III. København: Gyldendal 1953.

Sørensen, Sara, Katrine Rosendal Ehlers og Sten Vikner: 'Override'-refleksiver i dansk og engelsk. Ny Forskning i Grammatik 27. København 2020 (under udgivelse).

Tekster fra Danmarks middelalder og rencessance 1100-1550, https://tekstnet.dk/ (tilgået 16. december 2019).

Vikner, Sten: Parameters of Binder and of Binding Category in Danish. Working papers in Scandinavian Syntax 23, s. 1-61. Lund: Lunds Universitet 1985.

Vikner, Sten og Katrine Rosendal Ehlers: Sin, hendes og KorpusDK. Ny forskning $i$ Grammatik 24, s. 175-194. København 2017.

Wellejus, Gerd: Jysk, sjcellandsk eller skånsk? En undersøgelse af kriterierne for jysk dialekt, baseret på det gammeldanske lovsprog. København: Universitetsforlaget 1972 . 